\title{
Factors regulating ozone over the United States and its export to the global atmosphere
}

\section{Citation}

Jacob, Daniel J., Jennifer A. Logan, Geraldine M. Gardner, Rose M. Yevich, Clarisa M.

Spivakovsky, Steven C. Wofsy, Sanford Sillman, and Michael J. Prather. 1993. "Factors Regulating Ozone over the United States and Its Export to the Global Atmosphere." Journal of Geophysical Research 98 (D8): 14817. doi:10.1029/98jd01224.

\section{Published Version}

doi:10.1029/98JD01224

\section{Permanent link}

http://nrs.harvard.edu/urn-3:HUL.InstRepos:14121864

\section{Terms of Use}

This article was downloaded from Harvard University's DASH repository, and is made available under the terms and conditions applicable to Other Posted Material, as set forth at http:// nrs.harvard.edu/urn-3:HUL.InstRepos:dash.current.terms-of-use\#LAA

\section{Share Your Story}

The Harvard community has made this article openly available.

Please share how this access benefits you. Submit a story.

\section{Accessibility}




\title{
Factors Regulating Ozone Over the United States and Its Export to the Global Atmosphere
}

\author{
DANIEL J. JACOB, JENNIFER A. LOGAN, GERALDINE M. GARDNER, \\ RoSE M. YeVICH, Clarisa M. SPIVAKOVSKY, AND STEVEN C. WOFSY \\ Division of Applied Sciences and Department of Earth and Planetary Sciences, \\ Harvard University, Cambridge, Massachusetts
}

SANFORD SILLMAN

Department of Atmospheric, Oceanic and Space Sciences, University of Michigan, Ann Arbor

MiCHAEL J. PRATHER

Department of Earth Sciences, University of Califormia at Irvine

\begin{abstract}
The factors regulating summertime $\mathrm{O}_{3}$ over the United States and its export to the global atmosphere are examined with a 3-month simulation using a continental scale, three-dimensional photochemical model. It is found that reducing $\mathrm{NO}_{x}$ emissions by $50 \%$ from 1985 levels would decrease rural $\mathrm{O}_{3}$ concentrations over the eastern United States by about $15 \%$ under almost all meteorological conditions, while reducing anthropogenic hydrocarbon emissions by $50 \%$ would have less than a $4 \%$ effect except in the largest urban plumes. The strongly $\mathrm{NO}_{\mathrm{x}}$-limited conditions in the model reflect the doninance of rural areas as sources of $\mathrm{O}_{3}$ on the regional scale. The correlation between $\mathrm{O}_{3}$ concentrations and temperature observed at eastern U.S. sites is attributed in part to the association of high temperatures with regional stagnation, and in part to an actual dependence of $\mathrm{O}_{3}$ production on temperature driven primarily by conversion of $\mathrm{NO}_{\mathrm{x}}$ to peroxyacetylnitrate (PAN). The net number of $\mathrm{O}_{3}$ molecules produced per molecule of $\mathrm{NO}_{x}$ consumed (net $\mathrm{O}_{3}$ production efficiency, accounting for both chemical production and chemical loss of $\mathrm{O}_{3}$ ) has a mean value of 6.3 in the U.S. boundary layer; it is 3 times higher in the western United States than in the east because of lower $\mathrm{NO}_{\mathrm{x}}$ concentrations in the west. Approximately $70 \%$ of the net chemical production of $\mathrm{O}_{3}$ in the U.S. boundary layer is exported (the rest is deposited). Only $6 \%$ of the $\mathrm{NO}_{\mathrm{x}}$ emitted in the United States is exported out of the U.S. boundary layer as $\mathrm{NO}_{\mathrm{x}}$ or PAN, but this export contributes disproportionately to total U.S. influence on global tropospheric $\mathrm{O}_{3}$ because of the high $\mathrm{O}_{3}$ production efficiency per unit $\mathrm{NO}_{\mathrm{x}}$ in the remote troposphere. It is estimated that export of U.S. pollution supplies $8 \mathrm{Gmol} \mathrm{O}_{3} \mathrm{~d}^{-1}$ to the global troposphere in summer, including $4 \mathrm{Gmol} \mathrm{d}^{-1}$ from direct export of $\mathrm{O}_{3}$ out of the U.S. boundary layer and $4 \mathrm{Gmol} \mathrm{d}^{-1}$ from production of $\mathrm{O}_{3}$ downwind of the United States due to exported $\mathrm{NO}_{\mathrm{x}}$. This U.S. pollution source can be compared to estimates of 18-28 Gmol $\mathrm{d}^{-1}$ for the cross-tropopause transport of $\mathrm{O}_{3}$ over the entire northern hemisphere in summer.
\end{abstract}

\section{INTRODUCTION}

This paper is the second of two describing a continental scale, three-dimensional simulation of $\mathrm{O}_{3}$ and its precursors over North America for an entire summer. The first paper [Jacob et al., this issue] described the model and evaluated it with observations. Here we use the model to examine how emissions and meteorology determine $\mathrm{O}_{3}$ concentrations over the United States, and we estimate the exports of $\mathrm{O}_{3}$ and its precursors from the U.S. boundary layer to the global atmosphere.

Ozone is produced rapidly over the U.S. in summer by photochemical oxidation of non methane hydrocarbons (NMHCs) in the presence of nitrogen oxides $\left(\mathrm{NO}_{\mathrm{x}}=\mathrm{NO}+\mathrm{NO}_{2}\right)$. The NMHCs are emitted by a variety of anthropogenic and biogenic sources. The main source of $\mathrm{NO}_{x}$ is fossil fuel combustion. Production of $\mathrm{O}_{3}$ in a fresh combustion plume is usually NMHC limited, because of high concentrations of $\mathrm{NO}_{x}$, but shifts gradually to a $\mathrm{NO}_{\mathrm{x}}$-limited regime as the plume dilutes and $\mathrm{NO}_{\mathrm{x}}$ is oxidized [Chameides et al., 1988; Milford et al., 1989]. Production of $\mathrm{O}_{3}$ in rural air is primarily $\mathrm{NO}_{\mathrm{x}}$ limited because of low concentrations .

\section{Copyright 1993 by the American Geophysical Union.}

Paper number 98JD01224.

0148-0227/93/93JD-01224\$05.00 of $\mathrm{NO}_{\mathrm{x}}$ and high concentrations of the biogenic NMHC isoprene [Trainer et al., 1987; Sillman et al., 1990a; Chameides et al., 1992]. Three-dimensional model simulations of regional pollution episodes over the eastern U.S. indicate that $\mathrm{NO}_{\mathrm{x}}$ emission controls offer the best strategy for decreasing $\mathrm{O}_{3}$ maxima in rural areas [Possiel et al., 1990; McKeen et al., 1991]. We will take here a broader view by examining the effects of emission controls on $\mathrm{O}_{3}$ concentrations over the continental scale and over an entire summer.

Measurements of $\mathrm{O}_{3}$ concentrations at rural sites in the eastein United States indicate considerable variability from day to day and from year to year [Vukovich and Fishman, 1986; Logan, 1989]. The strongest correlation is with temperature; correlations with other meteorological variables such as wind speed and direction, pressure, cloud cover, and humidity are weak or absent [Wolff and Lioy, 1978; Clark and Karl, 1982; Korsog and Wolff, 1991]. The highest $O_{3}$ concentrations tend to be regional in scale and associated with weak, warm, stagnant anticyclones [Decker et al., 1976; Altshuller, 1978; Wolff and Lioy, 1980; Logan, 1989]. The model reproduces well these different features of the observations, as shown below, and offers insights into the actual dependences of $\mathrm{O}_{3}$ concentrations on meteorological variables.

Export of pollution-derived $\mathrm{O}_{3}$ and its precursors from the U.S. boundary layer may affect tropospheric $\mathrm{O}_{3}$ on the hem- 
ispheric scale, considering that the chemical lifetime of $\mathrm{O}_{3}$ is typically a week or more [Liu et al., 1987], and that the lifetime of the peroxyacetylnitrate (PAN) reservoir for $\mathrm{NO}_{\mathrm{x}}$ may be longer [Singh, 1987]. Observations suggest that tropospheric $\mathrm{O}_{3}$ in the northern hemisphere in summer is elevated ubiquitously by human activity [Logan, 1985; Fishman et al., 1990; Oltmans and Levy, 1993], and this view is supported by global models [Levy et al., 1985; Liu et al., 1987; Crutzen and Zimmerman, 1991; Follows and Austin, 1992]. We will present here quantitative estimates for the export fluxes of $\mathrm{O}_{3}$ and its precursors from the United States, and analyze the mechanisms for export.

The model is described briefiy in section 2 ; details are given by Jacob et al. [this issue]. The factors regulating $\mathrm{O}_{3}$ concentrations over the United States are discussed in section 3. The exports of $\mathrm{O}_{3}$ and $\mathrm{NO}_{\mathrm{x}}$ out of the U.S. boundary layer are analyzed in section 4 . Conclusions are in section 5 .

\section{THE MODEL}

The model solves the mass conservation equations for six chemical tracers on a three-dimensional gridded domain including all of North and Central America and large areas of the surrounding oceans (Figure 1). The horizontal resolution is $4^{\circ}$ latitude $\times 5^{\circ}$ longitude $\left(\approx 400 \times 400 \mathrm{~km}^{2}\right)$. There are nine layers in the vertical extending from the surface to the stratosphere along a sigma (terrain following) coordinate. The grid replicates that of the Goddard Institute for Space Studies general circulation model (GISS GCM 2). A one-summer archive of GISS GCM output [Hansen et al., 1983] is used as input to the model, including 4-hour averages of dynamical variables (winds, convective mass fluxes) and 5-day averages of other meteorological variables (temperature, cloud cover, humidity). Urban and industrial plumes are represented with a subgrid riested scheme that resolves chemical non linearity down to the $20-\mathrm{km}$ scale [Sillman et al., 1990 b].

The six tracers include odd oxygen (which is mainly $\mathrm{O}_{3}$ ), $\mathrm{NO}_{\mathrm{x}}$, PANs, $\mathrm{CO}$, a lumped NMHC with a lifetime of a few days representing a typical anthropogenic mix, and a lumped NMHC with a lifetime of less than a day contributed mainly by isoprene. The PANs tracer includes peroxyacetylnitrate (PAN) and higher peroxyacylnitrates. Chemical production and loss rates are computed with the detailed photochemical mechanism of Lurmann et al. [1986], modified as described by Jacob et al. [1989]. Oxidation of $\mathrm{NO}_{\mathrm{x}}$ to $\mathrm{HNO}_{3}$ and to organic nitrates other than PANs is viewed as a terminal sink for $\mathrm{NO}_{\mathrm{x}}$. Anthropogenic emissions of $\mathrm{NO}_{\mathrm{x}}, \mathrm{CO}$, and NMHCs in North America are taken from a summer 1985 inventory compiled by the National Acid Precipitation Assessment Program (NAPAP) [Environmental Protection Agency (EPA), 1989]. Anthropogenic emissions in Central and South America are estimated from data for energy use. Biogenic emission of isoprene is computed as a function of local vegetation type, temperature, and insolation [Tingey et al., 1979; Lamb et al., 1987]. Dry deposition fluxes of $\mathrm{O}_{3}, \mathrm{NO}_{\mathrm{x}}$, and PANs are computed with a resistance-in-series scheme dependent on local surface type and meteorological variables.

All simulations are conducted from May 15 to August 31 of the GCM year with a time step of 4 hours. The May 15-31 period is used for initialization. Boundary conditions are specified with observed background concentrations dependent on latitude, altitide, and month [Logan, 1985; Rudolph et al., 1987; Spivakovsky et al., 1990]. The stratospheric boundary conditions in the top two layers have negligible effect on the troposphere below because cross-tropopause transport is weak relative to horizontal transport in the troposphere across the lateral model boundaries. The background tropospheric $\mathrm{O}_{3}$ concentrations over the model domain are thus defined mainly by advection of the tropospheric boundary conditions.

Detailed evaluation of model results is presented in the companion paper. Median afternoon $\mathrm{O}_{3}$ concentrations simulated, at rural U.S. sites are typically within 5 ppb of observations, except in the south central United States where concentrations are overpredicted by $15-20 \mathrm{ppb}$. The overprediction in the south central United States is attributed to weaker-than-normal ventilation of that region in the GCM, and may also reflect insufficient resolu-

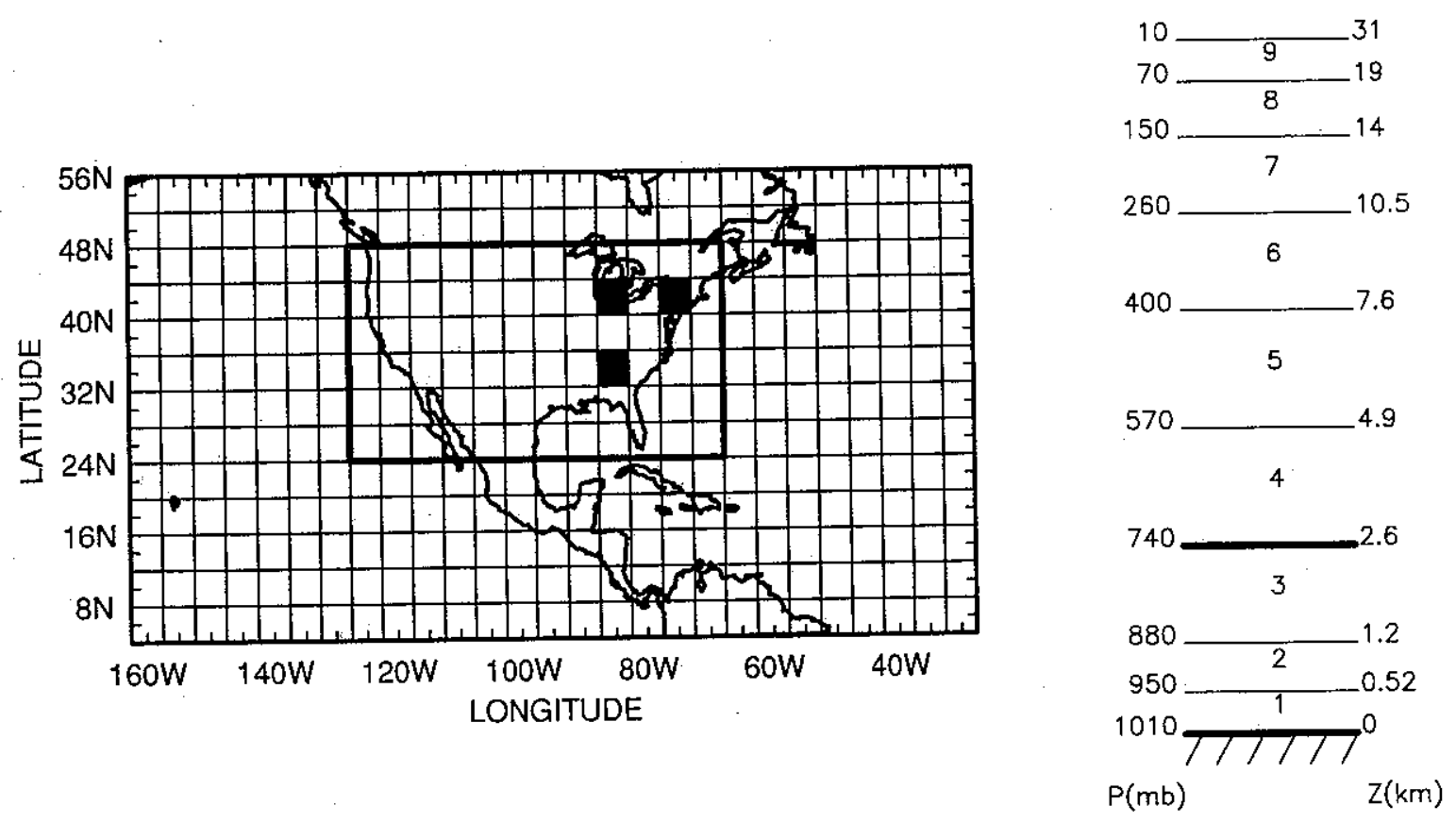

Fig. 1. Model domain and grid. The vertical grid is defined by a sigma coordinate and is shown here for an atmospheric column based at sea level. The thick line delineates the U.S. boundary layer $\left(127.5^{\circ} \mathrm{W}\right.$ to $67.5^{\circ} \mathrm{W}, 24^{\circ} \mathrm{N}$ to $48^{\circ} \mathrm{N}, 0-2.6 \mathrm{~km}$ column $)$. The Georgia, Michigan, and New York grid boxes are identified by shading. 
tion of $\mathrm{NO}_{x}$ point sources. The model simulates well the development of regional high- $\mathrm{O}_{3}$ episodes over the eastern United States in association with weak anticyclones. The variance of concentrations is less than observed, certainly in part because of local effects not resolved by the model. Simulated concentrations of $\mathrm{CO}$ and $\mathrm{NO}_{\mathrm{x}}$ are in good agreement with observations, while concentrations of PANs are overpredicted by factors of 2 to 3 . The overprediction of PANs is attributed to flaws in the Lurmann et al. [1986] chemical mechanism and may also reflect an underestimate of PANs deposition.

\section{RURAL OZONE OVER THE UNITED STATES}

\section{Effect of Emission Controls}

Figure 2 (top) shows the mean afternoon concentrations of $\mathrm{O}_{3}$ simulated in rural surface air using the NAPAP inventory of anthropogenic emissions for 1985. Reducing $\mathrm{NO}_{\mathrm{x}}$ emissions uniformly by $50 \%$ from that inventory results in a mean $10-15 \mathrm{ppb}$ decrease of rural $\mathrm{O}_{3}$ over the eastern U.S. (middle). Reducing anthropogenic NMHC emissions by $50 \%$ has less than a 3 ppb effect anywhere (bottom). Reducing both anthropogenic $\mathrm{NO}_{\mathrm{x}}$ and
NMHC emissions (not shown) has a nearly additive effect. The strongly $\mathrm{NO}_{\mathrm{x}}$-limited conditions in the model reflect the importance of rural areas as sources of $\mathrm{O}_{3}$ on the regional scale. We find that $82 \%$ of net $\mathrm{O}_{3}$ production in the U.S. boundary layer (see Figure 1 for definition) takes place in rural air, where $\mathrm{NO}_{\mathrm{x}}$ concentrations are relatively low. Only $18 \%$ takes place in the urban and industrial plumes represented by our nested subgrid scheme.

Figure 3 shows the cumulative probability distributions of summer afternoon $\mathrm{O}_{3}$ concentrations simulated in three eastern U.S. grid boxes (Georgia, Michigan, New York). The distributions are intended to be representative of rural sites in the grid boxes; they were constructed by sampling the time series of concentrations in rural air and in aged subgrid plumes on an areaweighted basis to account for occasional influence of pollution plumes over rural areas [Jacob et al, this issue]. We find that reducing $\mathrm{NO}_{x}$ emissions by $50 \%$ from 1985 levels decreases $\mathrm{O}_{3}$ concentrations by $15 \%$ over the full range of the summertime probability distribution, except for the highest occurrences in the New York grid box (aged New York City plume) which actually increase. Production of $\mathrm{O}_{3}$ in the New York City plume can remain NMHC limited for a long photochemical aging time because the urban source area is large, so that dilution of the plume is slow.
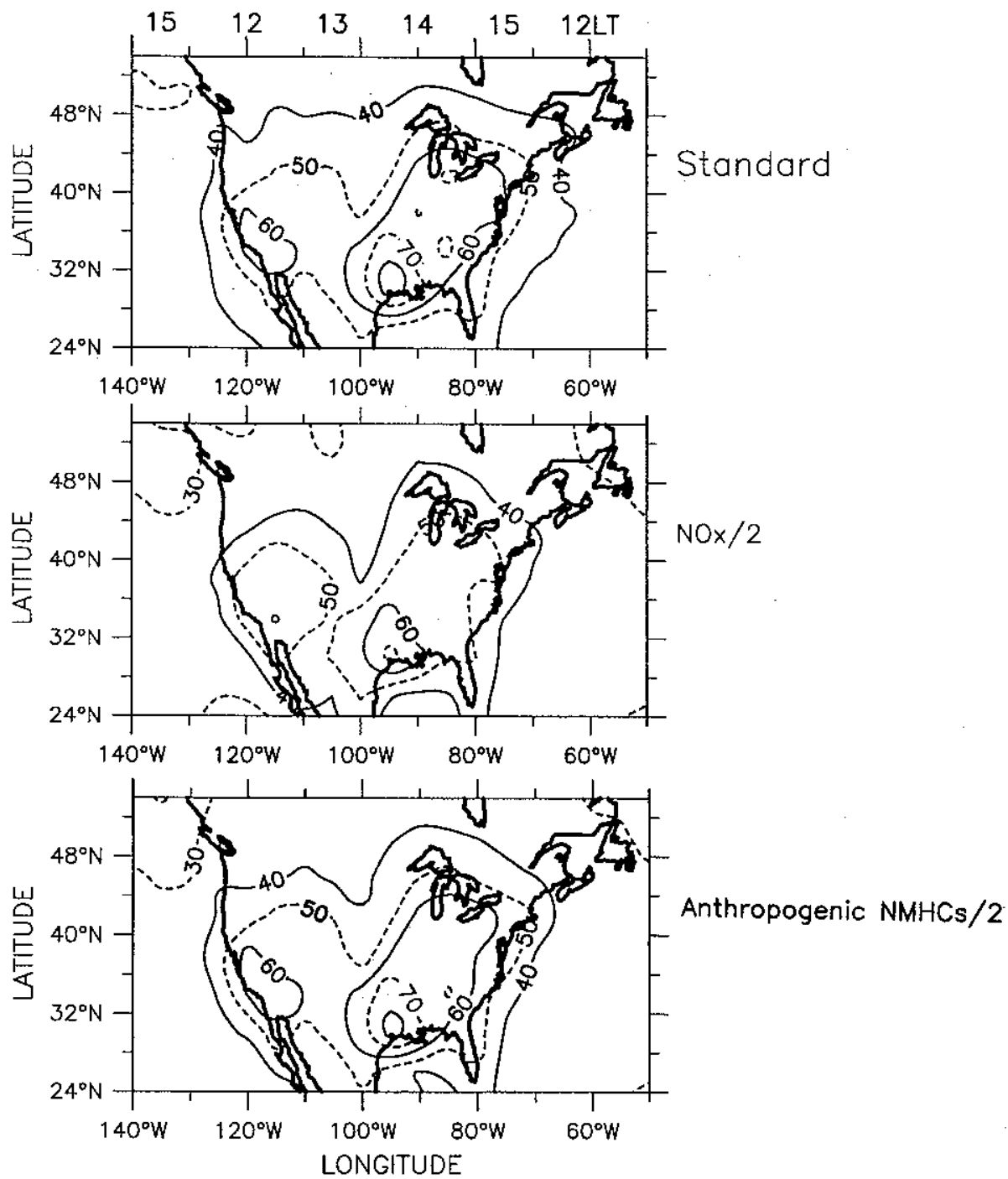

Fig. 2. Mean afternoon concentrations of $\mathrm{O}_{3}(\mathrm{ppb})$ simulated in rural air in July. The concentrations are for 12-15 local time (LT) in the lowest model layer (0-500 m altitude). Results from the standard simulation with anthropogenic emissions for 1985 (top panel) are compared to results from simulations with anthropogenic $\mathrm{NO}_{\mathrm{x}}$ or NMHC emissions reduced uniformly by $50 \%$. 


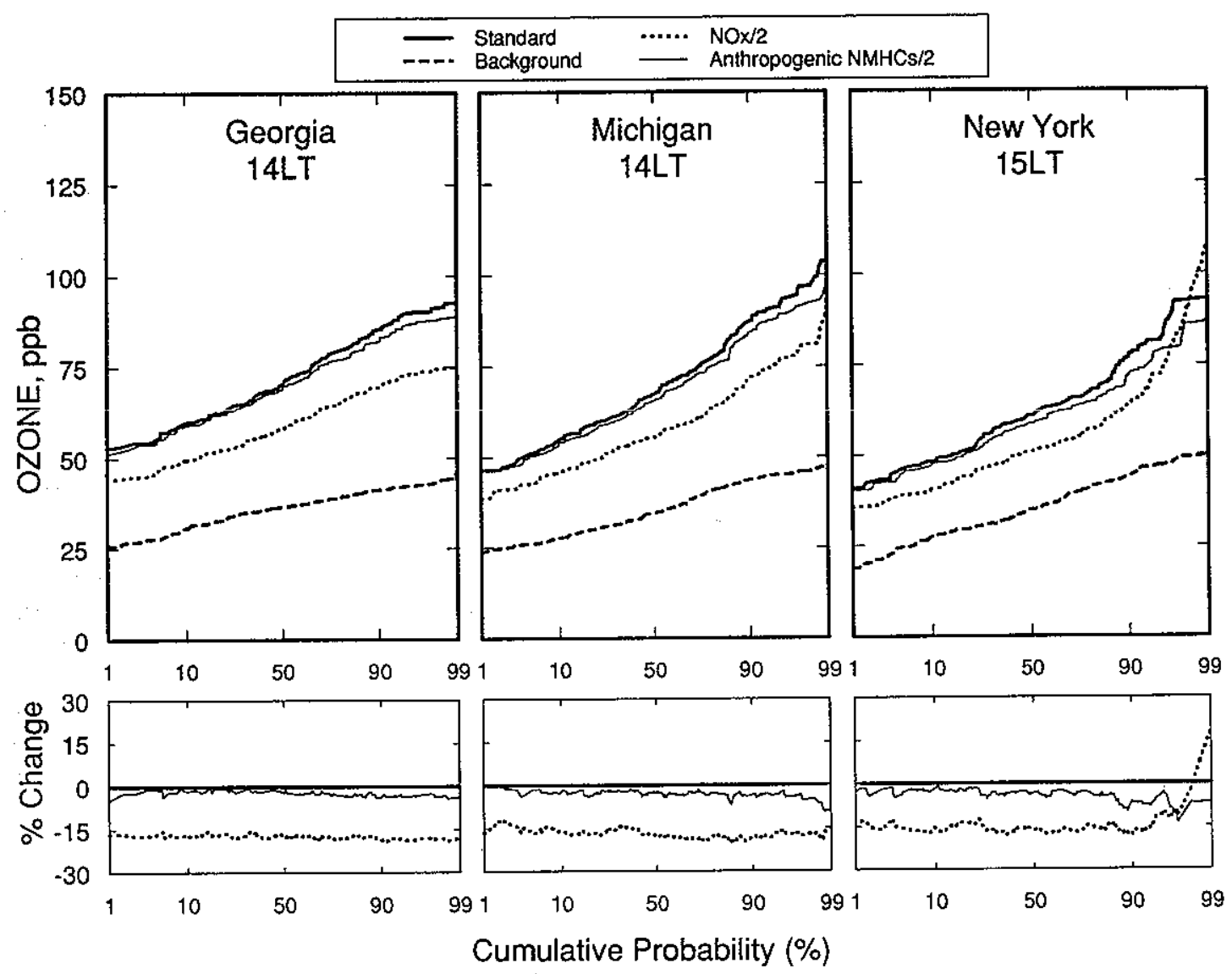

Fig. 3. Cumulative probability distributions of summer afternoon $\mathrm{O}_{3}$ concentrations simulated for rural sites in the Georgia, Michigan, and New York grid boxes. The scale of the abscissa is such that a normal distribution would plot as a straight line (probability scale). Results from the standard simulation with anthropogenic emissions for 1985 (bold lines) are compared to results from simulations with anthropogenic $\mathrm{NO}_{\mathrm{x}}$ or $\mathrm{NMHC}$ emissions reduced uniformly by $50 \%$ (dotted lines and thin lines, respectively). The dashed lines show the probability distributions for background $\mathrm{O}_{3}$ originating from outside North America, as obtained in a simulation including no chemistry (i.e., with concentrations regulated solely by advection of boundary conditions and deposition). The bottom panels show the percent changes of the different quantiles when anthropogenic $\mathrm{NO}_{\mathrm{x}}$ or $\mathrm{NMHC}$ emissions are reduced by $50 \%$.

Under strongly NMHC-limited conditions, $\mathrm{O}_{3}$ production increases when $\mathrm{NO}_{x}$ concentrations decrease [Sillman et al., 1990a].

Reducing anthropogenic NMHC emissions by $50 \%$ decreases rural $\mathrm{O}_{3}$ concentrations by less than $4 \%$ under all conditions in Figure 3, except for the highest occurrences in the Michigan and New York grid boxes (Detroit and New York City urban plumes). The Atlanta urban plume in the Georgia grid box is less sensitive to anthropogenic NMHC emissions because of higher temperatures and hence higher isoprene emissions. Ozone is particularly insensitive to anthropogenic NMHCs under relatively clean conditions (lower end of the cumulative probability distributions) because of the availability of isoprene as a rapid source of $\mathrm{O}_{3}$. Anthropogenic NMHCs are typically less reactive than isoprene, and are therefore more likely to be ventilated outside of the U.S. boundary layer before realizing their $\mathrm{O}_{3}$ production potential [Lin et al., 1988].

Our results for highly polluted conditions (higher end of the probability distributions in Figure 3) are consistent with previous studies of pollution episodes using three-dimensional regional models. McKeen et al. [1991] found in a 4-day simulation of a regional stagnation episode over the eastern United States that reducing $\mathrm{NO}_{\mathrm{x}}$ emissions by $50 \%$ from 1985 levels would decrease afternoon $\mathrm{O}_{3}$ concentrations by $12-16 \%$ in most areas but by less than $4 \%$ in the New York City plume, while reducing anthropo- genic NMHC emissions by $50 \%$ would decrease $\mathrm{O}_{3}$ concentrations by less than $4 \%$ in most areas but by $12-20 \%$ in the New York City plume. Simulations for the northeastern United States by Possiel et al. [1990] and Roselle et al. [1991] indicate that reducing anthropogenic NMHC emissions by 50\% from 1985 levels would decrease peak $\mathrm{O}_{3}$ concentrations by less than $10 \%$ except in large urban plumes, while reducing both $\mathrm{NMHC}$ and $\mathrm{NO}_{\mathrm{x}}$ emissions by about $30 \%$ would decrease peak $\mathrm{O}_{3}$ by $10-15 \%$ in most areas.

Although $\mathrm{NO}_{\mathrm{x}}$ emission controls seem to offer the best strategy for decreasing rural $\mathrm{O}_{3}$ concentrations in the eastern United States, the response is still relatively weak. A $50 \%$ reduction of $\mathrm{NO}_{x}$ emissions yields only a $15 \%$ decrease of $\mathrm{O}_{3}$ concentrations. There are two reasons for this weak sensitivity. First is chemical non linearity [Lin et al., 1988]; the net $\mathrm{O}_{3}$ production in the U.S. boundary layer decreases by only $33 \%$ on average when $\mathrm{NO}_{x}$ emissions are reduced by $50 \%$. Second is the presence of a substantial $\mathrm{O}_{3}$ background advected from outside North America, which we derive in the model by conducting a simulation with no chemistry (i.e., with concentrations regulated solely by advection of boundary conditions and deposition). The background contributes on average about half of surface $\mathrm{O}_{3}$ concentrations over the eastern United States in the model (see Figure 3 and also Jacob et al. [this issue]). This contribution is less during pollution ep- 
isodes, but the non-linear dependence of $\mathrm{O}_{3}$ production on $\mathrm{NO}_{x}$ concentration is then more pronounced, so that the response of $\mathrm{O}_{3}$ to $\mathrm{NO}_{\mathrm{x}}$ emission controls remains weak over the entire probability distribution.

\section{Sensitivity to Meteorological Variables}

Figure 4 shows the time series of rural afternoon $\mathrm{O}_{3}$ concentrations simulated by the model in the Georgia, Michigan, and New York grid boxes. The day-to-day variability is mainly driven by regional pollution; variability in the background is small (dashed lines) and is generally anticorrelated with pollution enhancements. The prominent oscillations in the Michigan and New York grid boxes are due to weak anticyclones traveling from central Canada across the eastern United States to the Atlantic. Ozone concentrations are low in the northerly flow on the frontside of the anticyclones, and high on the backside due to regional stagnation, consistent with observations [Jacob et al, this issue]. The Georgia grid box is less exposed to episodic influxes of cleaner air because it lies outside the principal anticyclone track, both in the GCM and in the observations [Harman, 1987].

We tested the ability of the model to reproduce the correlation between $\mathrm{O}_{3}$ concentrations and temperature in the observations by using as standard the nine eastern U.S. sites of the Sulfate Regional Experiment (SURE) [Mueller and Hidy, 1983]. Continuous observations at these sites are available for June-August of 1978 and 1979. The observed $\mathrm{O}_{3}$ concentrations at $14 \mathrm{LT}$ are significantly correlated with temperature at eight of the nine sites, with linear correlation coefficients $r$ ranging from 0.25 to 0.67 ( $n$ $=131-181$ points depending on the site). The same analysis in the model shows significant correlation at all nine sites with $r$ ranging from 0.50 to $0.82(n=92)$. The correlation coefficients are higher in the model, certainly in part because local sources of variance in the observations are not resolved.

The $\mathrm{O}_{3}$-temperature correlation in the observations may reflect in part a dependence of temperature on air mass origin or solar radiation [Sillman and Samson, 1993]. We diagnosed the actual sensitivity of $\mathrm{O}_{3}$ concentrations to temperature by conducting a simulation with temperature held constant in each grid box at its mean local value for June to August. Results in Figures 4 and 5 show that temperature accounts for $51 \%$ of the variance of afternoon $\mathrm{O}_{3}$ concentrations in the Georgia grid box, 26\% in Michigan and $20 \%$ in New York. Temperature is relatively more important in the southeast because the variability in air mass origin is less. High $-\mathrm{O}_{3}$ episodes develop over the northeastern United States even when temperatures are held constant (dotted lines in Figure 4), although the peak concentrations are decreased by about $5 \mathrm{ppb}$. We see that regional stagnation, rather than high temperature, is the primary forcing factor for the occurrence of high- $\mathrm{O}_{3}$ episodes. Part of the $\mathrm{O}_{3}$-temperature correlation reflects the association of high temperatures with regional stagnation [Jacob et al., this is sue].

The contribution of temperature to the $\mathrm{O}_{3}$ concentration variance indicates a significant dependence of $\mathrm{O}_{3}$ concentrations on temperature, which we examined in more detail by conducting simulations with temperatures held constant only in the chemical mechanism or in the calculation of isoprene emission. Results in Figure 5 show that most of the temperature dependence is due to the chemical mechanism, where it reflects principally the storage of $\mathrm{NO}_{\mathrm{x}}$ as PANs at low temperatures [Sillman et al., 1990a]. As pointed out above, the model overpredicts PANs concentrations, and therefore likely exaggerates the sensitivity of $\mathrm{O}_{3}$ concentrations to temperature. Mean afternoon concentration ratios

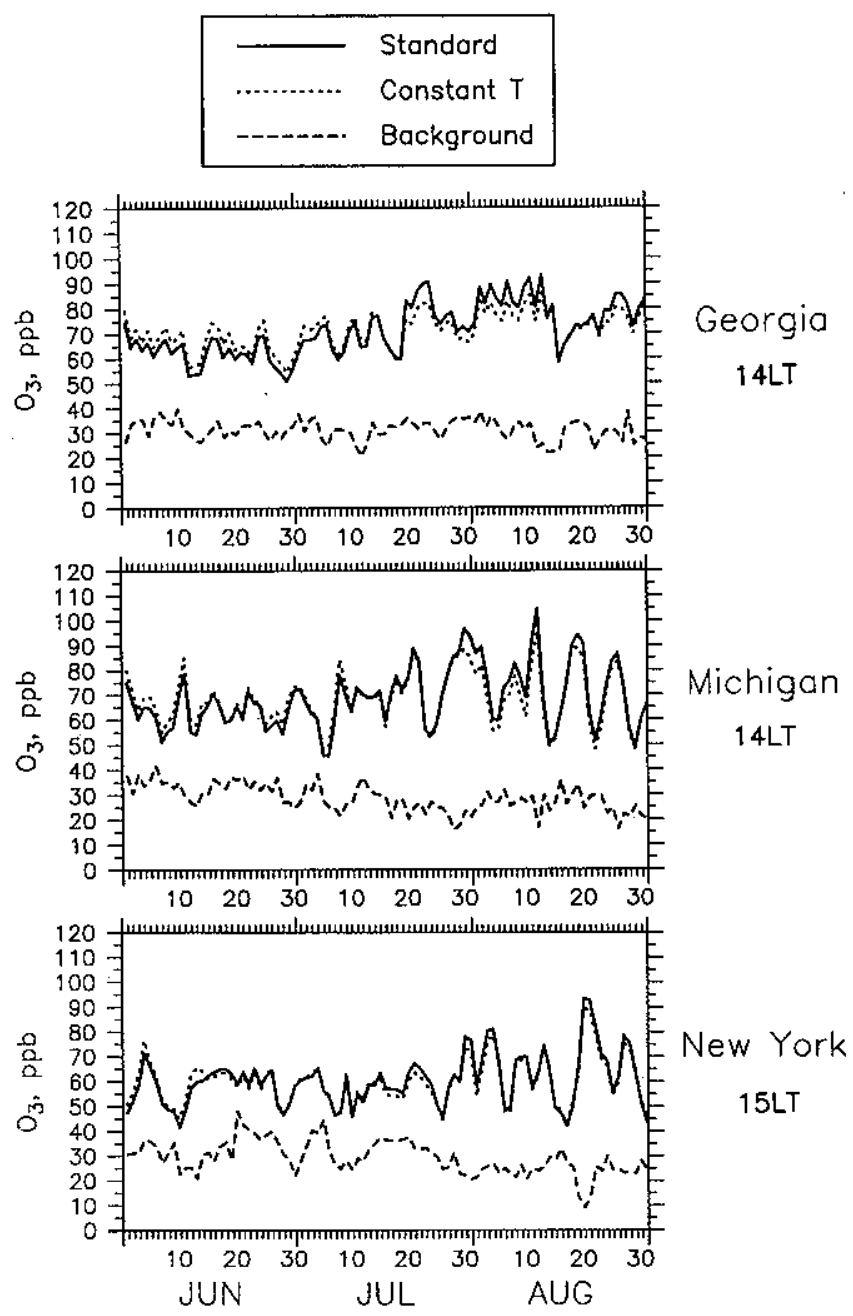

Fig. 4. Afternoon concentrations of rural $\mathrm{O}_{3}$ simulated in the Georgia, Michigan, and New York grid boxes. Results from the standard simulation (solid lines) are compared to results from a simulation with temperature held constant in each grid box at its local mean value for June-August (dotted lines). The dashed lines show the model background originating from outside North America.

PANs/ $/ \mathrm{NO}_{\mathrm{x}}(\mathrm{ppb} / \mathrm{ppb})$ at rural sites in the eastern United States are 2-3 in the model and 0.5-1 in the observations [Buhr et al., 1990; Parrish et al., 1993a]. The presence of a substantial PANs reservoir in the observations nevertheless implies a significant coupling of $\mathrm{O}_{3}$ concentrations and temperature through PANs decomposition.

The effect of temperature on isoprene emission makes only a small contribution to the variance of $\mathrm{O}_{3}$ concentrations (Figure 5) because $\mathrm{O}_{3}$ production is primarily $\mathrm{NO}_{x}$ limited. We conducted sensitivity simulations with isoprene emission increased or decreased uniformly by a factor of 2 from the standard simulation, corresponding in the model to a $7 \mathrm{~K}$ change in temperature; $\mathrm{O}_{3}$ concentrations changed by at most $4 \mathrm{ppb}$. Shutting off isoprene emission completely in the model led to $5-15 \mathrm{ppb}$ decreases of $\mathrm{O}_{3}$ concentrations over most of the eastern United States, consistent with previous results from regional models [McKeen et al., 1991; Roselle et al., 1991]. We conclude that although isoprene emission enhances $\mathrm{O}_{3}$ concentrations substantially relative to an isoprene-free atmosphere, the temperature dependence of isoprene emission is too weak to make a major contribution to the $\mathrm{O}_{3}$ temperature correlation. 


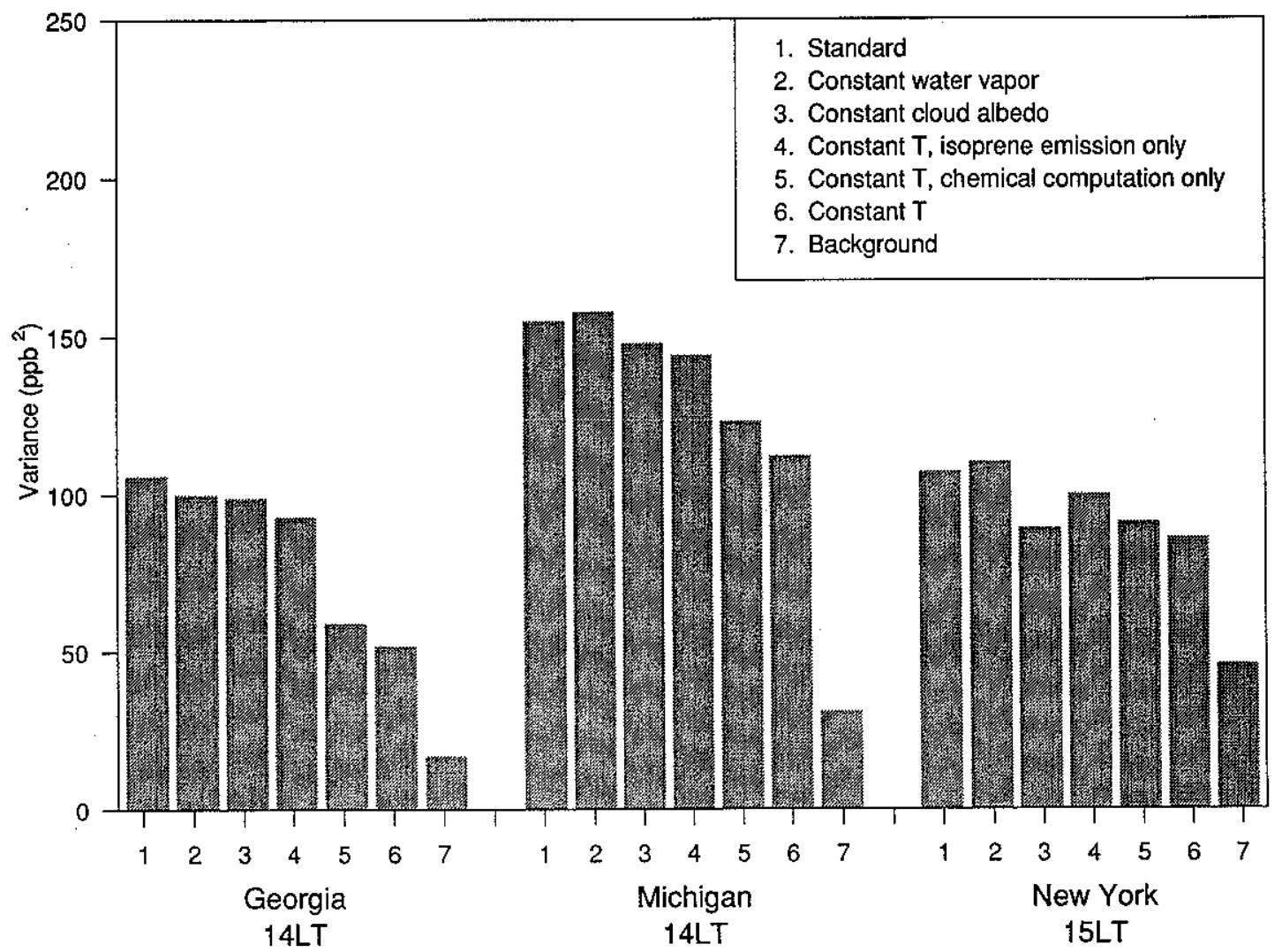

Fig. 5. Temporal variances of rural $\mathrm{O}_{3}$ concentrations in the Georgia, Michigan, and New York grid boxes, computed from the model time series for June-August sampled at 14 or $15 \mathrm{LT}(\mathrm{n}=92)$. Results are shown for the standard simulation, and for a series of sensitivity simulations with individual variables held constant in each grid box at their local mean value for June-August.

The sensitivity of $\mathrm{O}_{3}$ concentrations to cloud cover was examined using the same approach as for temperature. Cloud cover moderates $\mathrm{O}_{3}$ production, principally by slowing down $\mathrm{NO}_{2}$ photolysis; however, the cloud albedoes in the model (5-day averages) rarely exceed 0.4 , corresponding to a $40 \%$ decrease in photolysis. Because this effect is relatively small, the contribution of cloud cover to the $\mathrm{O}_{3}$ concentration variance is less than the contributions of dynamics or temperature. Our result is consistent with observations, which show only weak correlations of daytime $\mathrm{O}_{3}$ concentrations with cloud cover [Kelly et al., 1986; Korsog and Wolff, 1991]. It may however be that the weak sensitivity in the model is due to the 5-day averaging of cloud cover, while the weak correlation in the observations is due to the transient nature of clouds.

None of the other model variables make any significant contribution to the variance of $\mathrm{O}_{3}$ concentrations. In particular, water vapor is unimportant because of canceling influences on photochemistry [Sillman et al., 1990a]. This result is consistent with observations, which show that water vapor is not a significant predictor of $\mathrm{O}_{3}$ concentrations at eastern U.S. sites [Wolff and Lioy, 1978; Clark and Karl, 1982].

\section{GLoBAl INFLuence}

\section{Budgets of $\mathrm{O}_{3}$ and $\mathrm{NO}_{\mathrm{x}}$ in the U.S. Boundary Layer}

Figure 6 shows the net $\mathrm{O}_{3}$ production rates (chemical production minus chemical loss) computed in the U.S. boundary layer in July. We define here the U.S. boundary layer as the region bounded by the thick line in Figure 1, and extending vertically to $\approx 2.6 \mathrm{~km}$ above ground level (top of model layer 3 ). Production is maximum in a band between Texas and Michigan, reflecting a combination of high $\mathrm{NO}_{x}$ emissions, high isoprene emission, and weak ventilation $\left[J a c o b\right.$ et al., this issue]. The average net $\mathrm{O}_{3}$ production rate in the U.S. boundary layer for June to August is $6.4 \mathrm{Gmol} \mathrm{d}^{-1}$, including $2.9 \mathrm{Gmol} \mathrm{d}^{-1}$ in the western United States (west of $97.5^{\circ} \mathrm{W}$ ) and $3.5 \mathrm{Gmol} \mathrm{d}^{-1}$ in the eastern United States. The near symmetry in $\mathrm{O}_{3}$ production between west and east is remarkable considering that $\mathrm{NO}_{x}$ emissions are much weaker in the west $\left(0.25 \mathrm{Gmol} \mathrm{d}^{-1}\right)$ than in the east $\left(0.93 \mathrm{Gmol} \mathrm{d}^{-1}\right)$. The net $\mathrm{O}_{3}$ production efficiency $\varepsilon_{N}$, defined as the net number of $\mathrm{O}_{3}$ molecules produced per molecule of $\mathrm{NO}_{\mathrm{x}}$ consumed [Lin et al., 1988], is 3 times higher in the west $\left(\varepsilon_{\mathrm{N}}=12.4\right)$ than in the east $\left(\varepsilon_{\mathrm{N}}\right.$ = 4.4), due to lower $\mathrm{NO}_{\mathrm{x}}$ concentrations in the west that reflect

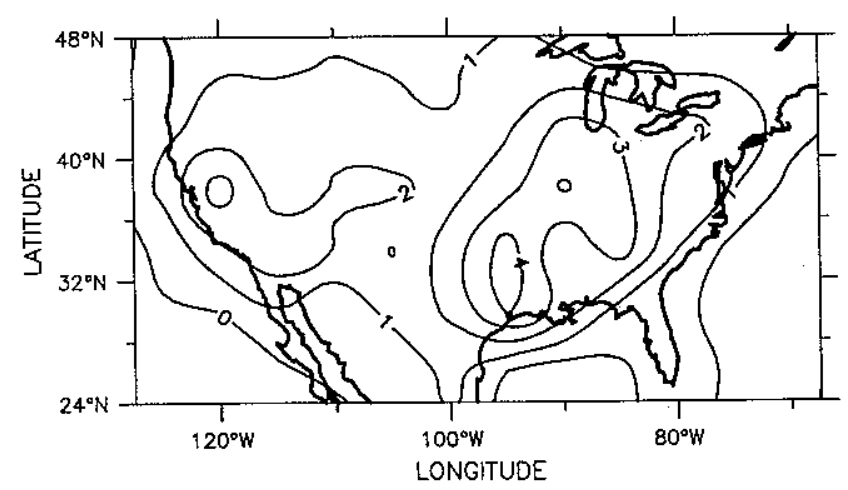

Fig. 6. Net $\mathrm{O}_{3}$ production rates $\left(10^{6}\right.$ molecules $\left.\mathrm{cm}^{-3} \mathrm{~s}^{-1}\right)$ computed in the model for the air column extending up to $\approx 2.6 \mathrm{~km}$ above the surface (top of model layer 3 ). Values are 24-hour means for July averaged over the. depth of the column. 
both weaker emissions and deeper boundary layer mixing. Summer afternoon mixing depths in the GCM are typically $2-2.5 \mathrm{~km}$ over the western United States and 1-1.5 km over the eastern United States, consistent with observations [Holzworth, 1967], and reflecting the stronger insolation and more arid terrain in the west.

Export of $\mathrm{O}_{3}$ and $\mathrm{NO}_{\mathrm{x}}$

Net photochemical production of $\mathrm{O}_{3}$ in the U.S. boundary layer in the model exceeds slightly the loss from deposition (6.4 versus $5.2 \mathrm{Gmol} \mathrm{d}^{-1}$ in June to August), so that the United States is a net exporter of $\mathrm{O}_{3}$. Export of pollution $\mathrm{O}_{3}$ from the United States is in fact much higher than this balance would indicate because part of the $\mathrm{O}_{3}$ deposited to the United States is exogenous. We extracted this exogenous background in a simulation with no chemistry, i.e., with $\mathrm{O}_{3}$ concentrations regulated solely by advection of boundary conditions and deposition. The residual "pollition $\mathrm{O}_{3}$ " represents the effect of net photochemical production over the model domain. We find that $70 \%$ of pollution $\mathrm{O}_{3}$ produced in the U.S. boundary layer is exported, representing an export flux of $4.3 \mathrm{Gmol} \mathrm{d}^{-1}$; the remaining $30 \%$ are deposited within the region: The residence time of pollution $\mathrm{O}_{3}$ in the U.S. boundary layer is 2.5 days (4 days against export, 8 days against deposition).

Parrish et al. [1993b] estimated recently an export flux of $1.1 \mathrm{Gmol} \mathrm{d}^{-1}$ for pollution $\mathrm{O}_{3}$ out of the eastern United States in summer. They arrived at this estimate by using variance ratios of $\mathrm{O}_{3}$ and $\mathrm{CO}$ concentrations measured at Canadian island sites, and scaling to the NAPAP inventory for CO emissions east of the Mississippi River (roughly east of $90^{\circ} \mathrm{W}$ ). We report elsewhere [Chin and Jacob, 1993] that the model reproduces well the variance ra- tios observed by Parrish et al: [1993b] and by other investigators in the eastern United States and downwind. We find however that the export flux of pollution $\mathrm{O}_{3}$ produced in the United States east of $90^{\circ} \mathrm{W}$ is $1.6 \mathrm{Gmol} \mathrm{d}^{-1}$, i.e., $45 \%$ higher than estimated by Parr ish et al. [1993b]. Chin and Jacob [1993] point out that the export estimate of Parrish et al. [1993b] is low because NMHC oxidation must be accounted for as a source of $\mathrm{CO}$, and because anticorrelation between background $\mathrm{O}_{3}$ and $\mathrm{CO}$ causes the variance ratio of $\mathrm{O}_{3}$ and $\mathrm{CO}$ concentrations to underestimate the actual $\mathrm{O}_{3} / \mathrm{CO}$ pollution ratio.

Figure 7 shows the mean transport fluxes of pollution $\mathrm{O}_{3}$ in the model in July. Export out of the U.S. boundary layer is principally by vertical transport to the free troposphere (70\% of total export) and by advection to Canada in the boundary layer (13\%). Ventilation to the free troposphere is particularly vigorous over the Rocky Mountains due to strong convergence of airflow from the western and south central United States [Wendland and Bryson, 1981]. Influx of pollution $\mathrm{O}_{3}$ from the western United States to the Rocky Mountains is facilitated by deep mixed layers, with strong winds at altitude, and also by subsidence along the west coast which forces pollution from California to the east.

Figure 8 shows the mean transport fluxes of $\mathrm{NO}_{x}$ in the model in July. The lifetime of $\mathrm{NO}_{x}$ against oxidation to $\mathrm{HNO}_{3}$ and to stable organic nitrates is 10 hours on average in the U.S. boundary layer. Net export of $\mathrm{NO}_{x}$ out of the U.S. boundary layer (averaging $0.07 \mathrm{Gmol} \mathrm{d}^{-1}$ for June to August) represents only $6 \%$ of $\mathrm{NO}_{\mathrm{x}}$ emissions in the region because of the short lifetime. Vertical transport to the free troposphere accounts for $87 \%$ of $\mathrm{NO}_{\mathrm{x}}$ export and is strongest over the northeastern United States where $\mathrm{NO}_{\mathrm{x}}$ emissions are high. Net export of PANs in the model is near zero $\left(<0.01 \mathrm{Gmol} \mathrm{d}^{-1}\right)$ because of conversion of $\mathrm{NO}_{x}$ to PANs in

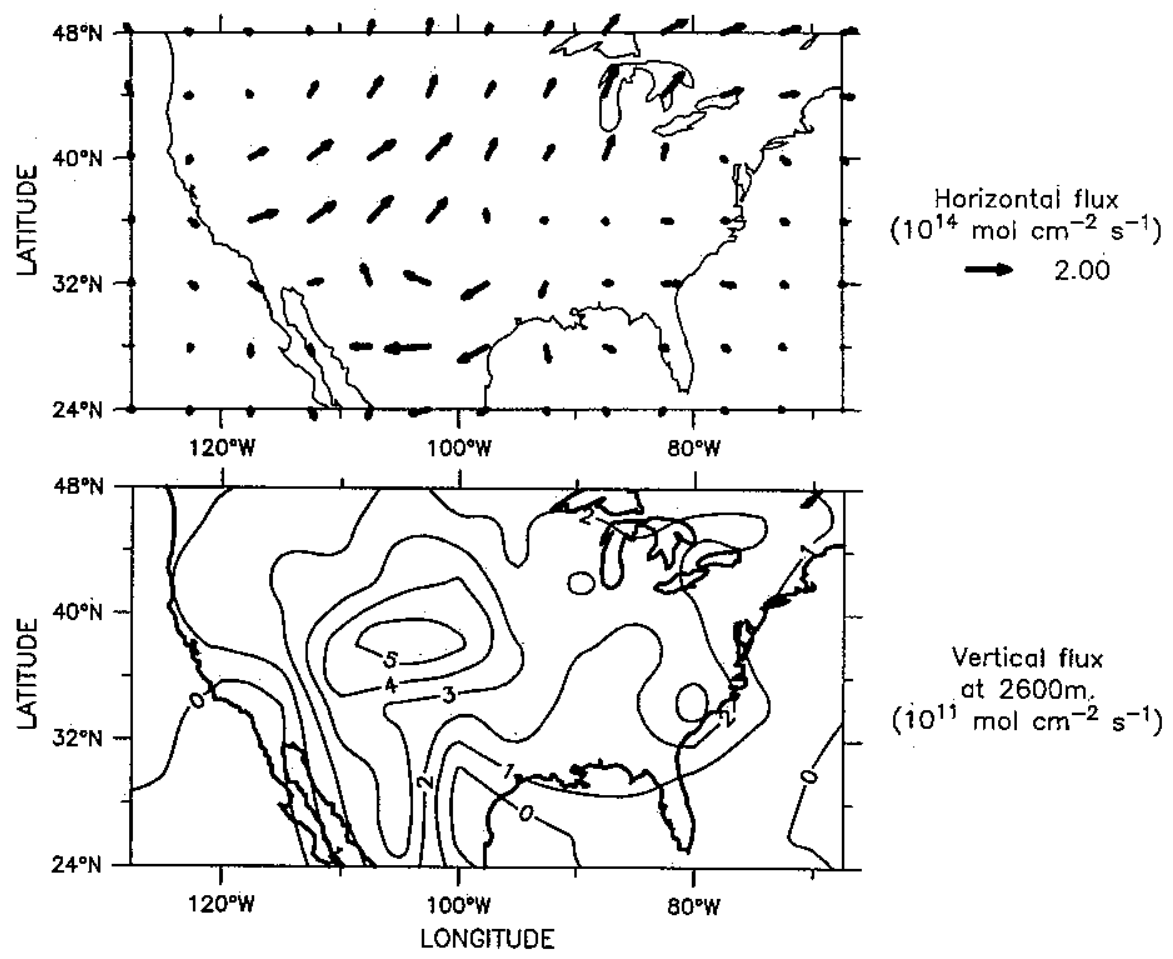

Fig. 7. Mean fluxes of pollution $\mathrm{O}_{3}$ computed in the model boundary layer in July. The fluxes represent the effect of net photochemical production of $\mathrm{O}_{3}$ over the model domain, and are obtained by subtracting the fluxes of background $\mathrm{O}_{3}$ from the fluxes of $\mathrm{O}_{3}$ computed in the standard simulation. The horizontal fluxes (top panel) are averages for the column extending up to $\approx 2.6 \mathrm{~km}$ above the surface (top of layer 3). The vertical fluxes (bottom panel) are computed at $\approx 2.6 \mathrm{~km}$ above the surface (through the top of model layer 3 ), and point upwards when positive. 


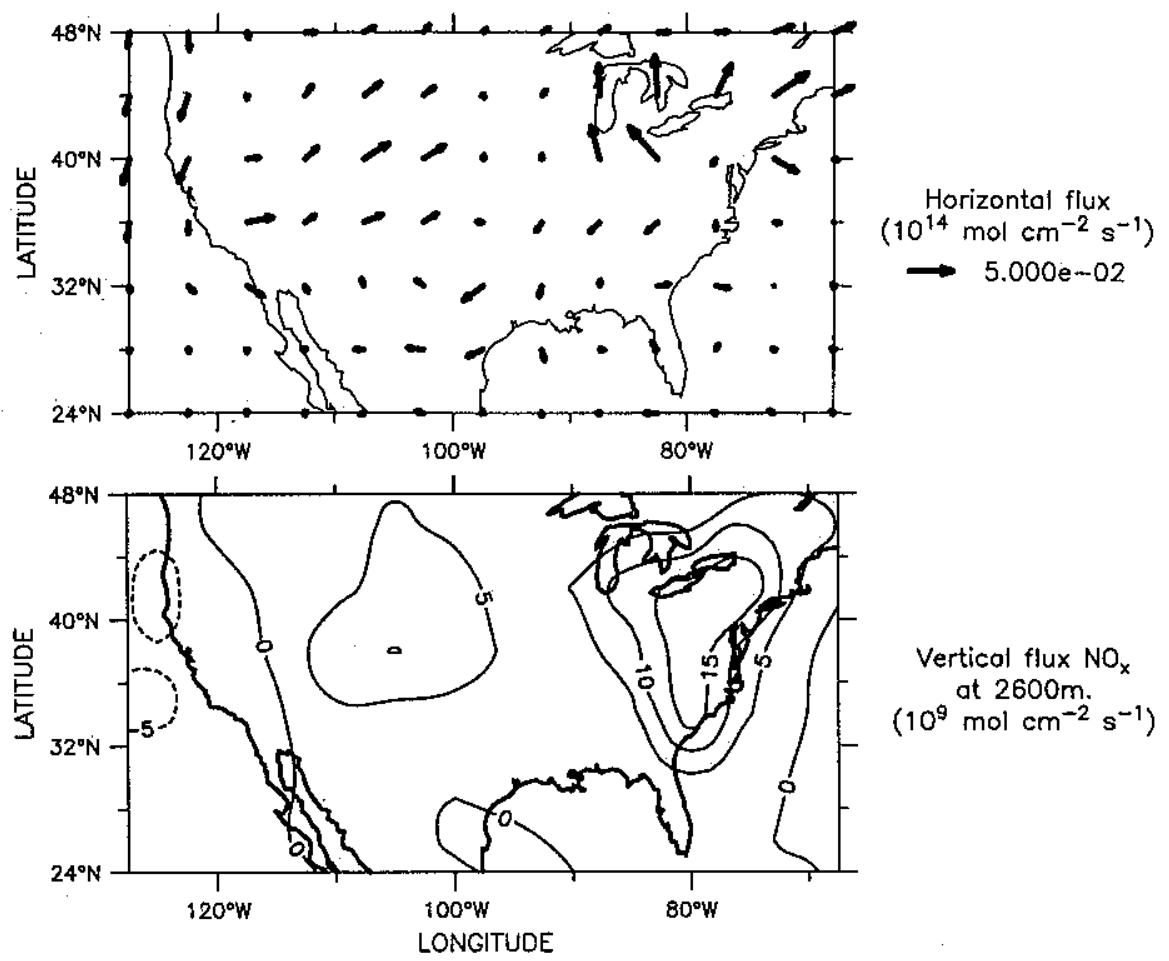

Fig. 8. Mean fluxes of $\mathrm{NO}_{\mathrm{x}}$ computed in the model boundary layer in July. The horizontal fluxes (top panel) are averages for the column extending up to $\approx 2.6 \mathrm{~km}$ above the surface (top of layer 3). The vertical fluxes (bottom panel) are computed at $\approx 2.6 \mathrm{~km}$ above the surface (through the top of layer 3 ), and point upwards when positive.

the middle troposphere followed by subsidence, resulting in a substantial PANs influx to the U.S: boundary layer. This result is consistent with one-dimensional photochemical model calculations by Kasting and Singh [1986] for northern mid-latitudes continental air in summer, showing zero net flux of PAN at 2-km altitude. We have, however, little confidence in our ability to simulate the export of PANs since concentrations are overpredicted. Kasibhatla et al. [1993] find in a global three-dimensional simulation of nitrogen oxides that $20 \%$ of $\mathrm{NO}_{\mathrm{x}}$ emitted from the United States in July is exported as $\mathrm{NO}_{\mathrm{y}}$ (including $\mathrm{NO}_{\mathrm{x}}, \mathrm{PAN}$, and $\mathrm{HNO}_{3}$ ). We find here that only $6 \%$ is exported as $\mathrm{NO}_{\mathrm{x}}$ or PANs, but $\mathrm{HNO}_{3}$ (which we do not simulate as a tracer) could account for a large fraction of total $\mathrm{NO}_{y}$ export.

\section{Global Influence}

Mean export fluxes of pollution $\mathrm{O}_{3}, \mathrm{NO}_{\mathbf{x}}$, and PANs out of the U.S. boundary layer in the model summer are 4.3, 0.07, and $<0.01 \mathrm{Gmol} \mathrm{d}^{-1}$, respectively. The exported $\mathrm{NO}_{x}$ produces $\mathrm{O}_{3}$ in the remote troposphere, but this production cannot be computed adequately in the model because of the limited spatial domain. We estimate instead the eventual $\mathrm{O}_{3}$ yield from the exported $\mathrm{NO}_{x}$ with a separate photochemical model calculation of the gross $\mathrm{O}_{3}$ production efficiency $\varepsilon_{G}$ [Liu et al., 1987], defined as the gross number of $\mathrm{O}_{3}$ molecules produced per molecule of $\mathrm{NO}_{\mathrm{x}}$ consumed ( $\varepsilon_{\mathrm{G}}$ differs from $\varepsilon_{\mathrm{N}}$ in that it does not account for $\mathrm{O}_{3}$ chemical loss). We obtain $\varepsilon_{\mathrm{G}}=57$ in a diel steady-state calculation for an air parcel at 4-km altitude in northern mid-latitudes summer with 40 ppt $\mathrm{NO}_{\mathrm{x}}$ [Carroll et al., 1992; Sandholm et al., 1993], $50 \mathrm{ppb}$ $\mathrm{O}_{3}, 100 \mathrm{ppb} \mathrm{CO}$, temperature $265 \mathrm{~K}, 50 \%$ relative humidity, clear skies, surface albedo 0.1 , and an $\mathrm{O}_{3}$ column of 325 Dobson units. The calculation ignores the loss of $\mathrm{NO}_{x}$ from hydrolysis of $\mathrm{N}_{2} \mathrm{O}_{5}$ on aerosol surfaces because we assume that the background aero- sol surface area in the middle troposphere (where most of the $\mathrm{NO}_{\mathrm{x}}$ is exported) is small. The value of $\varepsilon_{G}$ depends on a number of variables, in particular the concentration of $\mathrm{NO}_{x}$ [Liu et al., 1987]. The above calculation with $100 \mathrm{ppt} \mathrm{NO}_{\mathrm{x}}$ yields $\varepsilon_{\mathrm{G}}=36$. Assuming $\varepsilon_{\mathrm{G}}=57$, we derive an $\mathrm{O}_{3}$ source of $4.0 \mathrm{Gmol} \mathrm{d}^{-1}$ from export of $\mathrm{NO}_{x}$ out of the U.S. boundary layer. This source is of similar magnitude to direct export of anthropogenic $\mathrm{O}_{3}$.

We thus estimate that export of U.S. pollution supplies 8 Gmol d $\mathrm{d}^{-1} \mathrm{O}_{3}$ to the global troposphere in summer $\left(4.3 \mathrm{Gmol} \mathrm{d}^{-1}\right.$ from direct export, $4.0 \mathrm{Gmol} \mathrm{d}^{-1}$ from export of $\mathrm{NO}_{\mathrm{x}}$ ). This source can be compared to estimates of $18-28 \mathrm{Gmol} \mathrm{d}^{-1}$ for the cross-tropopause flux of $\mathrm{O}_{3}$ in the northern hemisphere in summer [Danielsen and Mohnen, 1977; Gidel and Shapiro, 1980; Mahlman et al., 1980]. We conclude that U.S. pollution makes a substantial contribution to tropospheric $\mathrm{O}_{3}$ on the hemispheric scale. The United States are responsible for about $30 \%$ of total $\mathrm{NO}_{x}$ emissions from fossil fuel combustion in the northêfn hemisphere [Dignon, 1992]. Scaling our results to the remaining $70 \%$ suggests that fossil fuel combustion and stratospheric input represent $\mathrm{O}_{3}$ sources of comparable magnitude in the northern hemisphere troposphere in summer.

\section{CONCLUSION}

We have used a continental scale, three-dimensional simulation of tropospheric photochemistry over North America in summer to reach a number of conclusions regarding regional and global influences of U.S. emissions on tropospheric $\mathrm{O}_{3}$. Some of the conclusions appear robust; others are uncertain and stress the need for further work.

We find that $\mathrm{NO}_{\mathrm{x}}$ emission controls offer the only viable strategy for decreasing summertime levels of $\mathrm{O}_{3}$ in the rural United States. This result is consistent with previous regional model 
studies focusing on pollution episodes. The response of $\mathrm{O}_{3}$ to $\mathrm{NO}_{x}$ emission controls is however relatively weak; a $50 \%$ reduction of $\mathrm{NO}_{x}$ emissions affords only a $15 \%$ decrease of $\mathrm{O}_{3}$ concentrations in the eastern United States under most conditions. Part of the reason is chemical non linearity and part is the presence of a substantial $\mathrm{O}_{3}$ background advected from outside North America. This background, specified in our model by boundary conditions, has a natural component but may also include significant contributions from Asian, European, and North American pollution circulated on a hemispheric scale. Abating $\mathrm{O}_{3}$ concentrations in the United States may thus call for an international strategy of emission controls; this issue needs to be explored further with a hemispheric scale model.

The occurrence of regional high- $\mathrm{O}_{3}$ episodes over the eastern United States in summer appears to be driven primarily by regional stagnation, rather than by high temperatures. The consistent correlation observed between $\mathrm{O}_{3}$ concentrations and temperature at eastern U.S. sites reflects in part an association of high temperatures with air mass origin, and in part an actual dependence of $\mathrm{O}_{3}$ production on temperature driven by the equilibrium between $\mathrm{NO}_{x}$ and PAN. The model overpredicts PAN concentrations and therefore probably exaggerates the dependence of $\mathrm{O}_{3}$ production on temperature. Nevertheless, the presence of substantial PAN concentrations in the obscrvations at U.S. sites suggests significant coupling of $\mathrm{O}_{3}$ concentrations and temperature through PAN decomposition.

The net $O_{3}$ production efficiency $\varepsilon_{N}$, defined as the net number of $\mathrm{O}_{3}$ molecules produced per molecule of $\mathrm{NO}_{x}$ consumed, has a mean model value of 6.3 in the U.S. boundary layer. This value appears to be well constrained by the good simulation of $\mathrm{O}_{3}$ concentrations and the good representation of boundary layer ventilation. Values of $\varepsilon_{N}$ are about 3 times higher in the western United States than in the east because of lower $\mathrm{NO}_{\mathrm{x}}$ concentrations in the west, reflecting both weaker $\mathrm{NO}_{\mathrm{x}}$ emissions and deeper mixing. Reducing $\mathrm{NO}_{x}$ emissions in the western United States is thus far more effective for decreasing $\mathrm{O}_{3}$ production on a per molecule basis than reducing $\mathrm{NO}_{x}$ emissions in the east.

On average, $70 \%$ of the net $\mathrm{O}_{3}$ production in the U.S. boundary layer is exported $\left(4.3 \mathrm{Gmol} \mathrm{d}^{-1}\right)$, while $30 \%$ is deposited within the region. This result appears robust since the characteristic times for $\mathrm{O}_{3}$ deposition and boundary layer ventilation are fairly well constrained. Most of the export is by ventilation to the free troposphere. The export is particularly strong over the Rocky Mountains because of convergence of air from the western and south-central United States. Pollution from California is forced eastward toward the Rocky Mountains by strong subsidence along the Pacific coast.

Net export of $\mathrm{NO}_{x}$ out of the U.S. boundary layer in the model represents only $6 \%$ of emissions in the region, reflecting the short lifetime of $\mathrm{NO}_{\mathrm{x}}$ against oxidation to stable products. Net export of PANs is negligible because the PANs outflow is balanced by conversion of $\mathrm{NO}_{\mathrm{x}}$ to PANs in the middle troposphere, followed by subsidence of PANs to the boundary layer. However the model overpredicts PANs, leaving much uncertainty in the computed budget for that species. We estimate that the small fraction of $\mathrm{NO}_{\mathrm{x}}$ exported from the U.S. boundary layer contributes as much $\mathrm{O}_{3}$ on the global scale as the $94 \%$ oxidized within the boundary layer, reflecting the high $\mathrm{O}_{3}$ production efficiency per unit $\mathrm{NO}_{\mathrm{x}}$ in the remote troposphere computed from photochemical mechanisms. There are however no good observations to evaluate this $\mathrm{O}_{3}$ production efficiency.

Our best estimate is that export of U.S. pollution supplies 8 Gmol $\mathrm{O}_{3} \mathrm{~d}^{-1}$ to the global troposphere in summer $\left(4.3 \mathrm{Gmol} \mathrm{d}^{-1}\right.$ from direct export, $4.0 \mathrm{Gmol} \mathrm{d}^{-1}$ from export of $\mathrm{NO}_{\mathrm{x}}$ ). The estimate of $\mathrm{O}_{3}$ export appears reliable, but the estimate of the $\mathrm{O}_{3}$ source from $\mathrm{NO}_{\mathrm{x}}$ export is highly uncertain. A source of $8 \mathrm{Gmol}$ $\mathrm{d}^{-1}$ represents about one third of the cross-tropopause transport of $\mathrm{O}_{3}$ over the entire northern hemisphere. We conclude that U.S. pollution makes a substantial contribution to tropospheric $\mathrm{O}_{3}$ on the hemispheric scale.

Acknowledgments. This paper benefited significantly from discussions with D.D. Parrish, M. Trainer, our colleague M. Chin, and from comments by H. Levy II and an anonymous reviewer. Support was provided by the the Coordinating Research Council (project AP-9), the Environmental Protection Agency (EPA-R814535-01-0), the National Aeronautics and Space Administration (NASA-NAGW-1230), the National Science Foundation (NSF-ATM-88-58074 and NSF-ATM-89-21119), and the Packard Foundation.

\section{REFERENCES}

Altshuller, A.P., Association of oxidant episodes with warm stagnating anticyclones, J. Air Pollut. Control Assoc., 28, 152-155, 1978.

Buhr, M. P., D. D. Parrish, R. B. Norton, F. C. Fehsenfeld, R. E. Sievers, and J. M. Roberts, Contribution of organic nitrates to the total reactive nitrngen budget at a rural Eastern U.S. site, J. Genphys. Res., 95, 9809$9816,1990$.

Carroll, M.A., B.A. Ridley, D.D. Montzka, G. Hubler, J.G. Walega, R.B. Norton, B.J. Huebert, and F.E. Grahek, Measurements of nitric oxide and nitrogen dioxide during the Mauna Loa Observatory Photochemistry Experiment, J. Geophys. Res., 97, 10,361-10,374, 1992.

Chameides, W.L., R.W. Lindsay, J: Richardson, and C.S. Kiang, The role of biogenic hydrocarbons in urban photochemical smog: Atlanta as a case study, Science, 241, 1473-1475, 1988.

Chameides, W.L., et al., Ozone precursor relationships in the ambient atmosphere, J. Geophys. Res., 97, 6037-6055, 1992.

Chin, M., and D.J. Jacob, Relationship of $\mathrm{O}_{3}$ and CO concentrations over North America and its implication on $\mathrm{O}_{3}$ production and transport (abstract), EOS Trans. AGU, 74(16), Spring Meeting suppl., 65, 1993.

Clark, T.L., and T.R. Karl, Application of prognostic meteorological variables to forecasts of daily maximum one-hour ozone concentrations in the northeastern United States, J. Appl. Meteorol., 21, 1662-1671, 1982.

Crutzen, P.J., and P.H. Zimmernann, The changing photochemistry of the troposphere, Tellus, 43(AB), 136-151, 1991.

Danielsen, E.F., and V. Mohnen, Project Duststorm: ozone transport in situ measurements, and meteorological analysis of tropopause folding, $J$. Geophys. Res., 82, 5867.5877, 1977.

Decker, C.E., L.A. Ripperton, J.J.B. Worth, F.M. Vukovich, W.D. Bach, J.B. Tommerdahl, F. Smith, and D.E. Waggoner, Formation and transport of oxidants along the Gulf coast and in northern U.S., EPA Rep., EPA-45013-76-003, Environ. Protec. Agency, Research Triangle Park, N. C., 1976.

Dignon, J., $\mathrm{NO}_{\mathrm{x}}$ and $\mathrm{SO}_{\mathrm{x}}$ emissions from fossil fuels: A global distribution, Atmos. Environ., 26(A), 1157-1164, 1992.

Environmental Protection Agency (EPA), The 1985 NAPAP emission inventory (version 2): development of the annual data and modeler's tapes, EPA Rep., EPA-600/7-89-012a, Research Triangle Park, N. C., 1989.

Fishman, J., C.E. Watson, J.C. Larsen, and J.A. Logan, Distribution of tropospheric ozone determined from satellite data, J. Geophys. Res., 95, 3599-3618, 1990.

Follows, M.J., and J.F. Austin, A zonal average model of the stratospheric contributions to the tropospheric ozone budget, J. Geophys. Res., 97. 18,047-18,060, 1992.

Gidel, L.T., and M.A. Shapiro, General circulation estimates of the net vertical flux of ozone in the lower stratosphere and the implications for the tropospheric ozone budget, J. Geophys. Res., 85, 4049-4058, 1980.

Hansen, J., Russell, G., Rind, D., Stone, P., Lacis, A., Lebedeff, S., Ruedy, 
R. and Travis, L., Efficient three-dimensional global models for climate studies: Models I and II, Mon. Weather Rev., 111, 609-662, 1983.

Harman, J.R., Mean monthly North American anticyclone frequencies, 1950-79, Mon. Weather Rev., 115, 2840-2848, 1987.

Holzworth, G.C., Mixing depths, wind speeds and air pollution potentials for selected locations in the United States, J. Appl. Meterol., 6, 1039. 1044, 1967.

Jacob, D. J., S. Sillman, J. A. Logan, and S. C. Wofsy, Least independent variable method for simulation of tropospheric ozone, J. Geophys. Res., 94, 8497-8510, 1989.

Jacob, D.J., et al., Simulation of summertime ozone over North America, $J$. Geophys. Res., this issue.

Kasibhatla, P.S., H. Levy II, and W.J. Moxim, Global $\mathrm{NO}_{\mathrm{x}}, \mathrm{HNO}_{3}$, PAN, and $\mathrm{NO}_{\mathrm{y}}$ distributions from fossil-fuel combustion emissions: A model study, J, Geophys. Res., in press, 1993.

Kasting, J.F., and H.B. Singh, Nonmethane hydrocarbons in the troposphere: Impact on the odd hydrogen and odd nitrogen chemistry, J. Geophys. Res., 91, 13,239-13,256, 1986.

Kelly, N.A., M.A. Ferman, and G.T. Wolff, The chemical and meteorological conditions associated with high and low ozone concentrations in southeastern Michigan and nearby areas of Ontario, J. Air Pollut. Control Assoc., 36, 150-158, 1986.

Korsog, P.E., and G.T. Wolff, An examination of urban ozone trends in the northeastern U.S. (1973-1983) using a robust statistical method, Atmos. Environ., 25B, 47-57, 1991.

Lamb, B., A. Guenther, D. Gay, and H. Westberg, A national inventory of biogenic hydrocarbon emissions, Atmos. Environ., 21, 1695-1706, 1987.

Levy, H., II, J.D. Mahlman, W.J. Moxim, and S.C. Liu, Tropospheric ozone: The role of transport, J. Geophys. Res., 90, 3753-3772, 1985.

Lin, X., M. Trainer, and S.C. Liu, On the nonlinearity of tropospheric ozone production, J. Geophys. Res., 93, 15,879-15,888, 1988.

Liu, S.C., M. Trainer, F.C. Fehsenfeld, D.D. Partish, E.J. Williams, D.W. Fahey, G. Hubler, and P.C. Murphy, Ozone production in the rural troposphere and the implications for regional and global ozone distributions, J. Geophys. Res., 92, 4191-4207, 1987.

Logan, J.A., Tropospheric ozone: Seasonal behavior, trends and anthropogenic influence, J. Geophys. Res., 91, 10,463-10,482, 1985.

Logan, J. A., Ozone in rural areas of the United States, J. Geophys. Res., 94, 8511-8532, 1989.

Luimann, F.W., A.C. Lloyd, and R. Atkinson, A chemical mechanism for use in long-range transport/acid deposition computer modeling, J. Geophys. Res., 91, 10,905-10,936, 1986.

Mahlman, J.D., H. Levy II, and W.J. Moxim, Three-dimensional tracer structure and behavior as simulated in two ozone precursor experiments, J. Atmos. Sci., 37, 655-685, 1980.

McKeen, S.A., E.-Y. Hsie, and S.C. Liu, A study of the dependence of rural ozone on ozone precursors in the eastern United States, J. Geophys. Res., 96, 15,377-15,394, 1991.

Milford, J.B., A.G. Russell, and G.J. McRae, A new approach to photochemical pollution control: Implications of spatial patterns in pollutant responses to reductions in nitrogen oxides and reactive organic gas emis: sions, Environ. Sci. Technol., 23, 1290-1301, 1989.

Mueller, P.K., and G.M. Hidy, The sulfate regional experiment: Report of findings, Rep. EA-1901 (3 volumes), Elec. Power Res. Inst., Palo Alto, Calif., 1983.

Oltmans, S.J., and H. Levy II, Ozone measurements from a global network of surface sites, in Proceedings of the 1992 Quadrennial Ozone Symposium, in press, 1993.

Parrish, D.D., et al., The total reactive oxidized nitrogen levels and the partitioning between the individual species at six rural sites in eastern North America, J. Geophys. Res., 98, 2927-2939, 1993a.
Parrish, D.D., J.S. Holloway, M. Trainer, P.C. Murphy, G.L. Forbes, and F.C. Fehsenfeld, Export of North American ozone pollution to the North Atlantic Ocean, Science, 259, 1436-1439, 1993 b.

Possiel, N.C., D.C. Doll, K.A. Baugues, E.W. Baldridge, and R.A. Wayland, Impacts of regional control strategies on ozone in the northeastern United States, Paper 90-93.3, paper presented at the 83rd Annual Meeting, Air and Waste Manage. Assoc., Pittsburgh, Pa, 1990.

Roselle, S.J., T.E. Pierce, and K.L. Schere, The sensitivity of regional ozone modeling to biogenic hydrocarbons, J. Geophys. Res., 96, 73717394, 1991.

Rudolph, J., B. Vierkorn-Rudolph, and F.X. Meixner, Large-scale distribution of peroxyacetylnitrate: Results from the STRATOZ III flights, $J$. Geophys. Res., 92, 6653-6661, 1987.

Sandholm, S., et al., Summertime partitioning and budget of $\mathrm{NO}_{\mathrm{y}}$ compounds in the troposphere over Alaska and Canada: ABLE 3, J. Geophys. Res., in press, 1993.

Sillman, S., and P. J. Samson, The impact of temperature on oxidant photochemistry in urban, polluted rural and remote environments, J. Geophys. Res., in press, 1993.

Sillman, S., J. A. Logan, and S. C. Wofsy, The sensitivity of ozone to nitrogen oxides and hydrocarbons in regional ozone episodes, $J$. Geophys. Res., 95, 1837-1852, 1990a.

Sillman, S., J.A. Logan, and S.C. Wofsy, A regional scale model for ozone in the United States with subgrid representation of urban and power plant plumes, J. Geophys. Res., 95, 5731-5748, 1990b.

Singh, H.B., Reactive nitrogen in the troposphere, Environ. Sci. Technol., 21, 320-327, 1987.

Spivakovsky, C.M., R. Yevich, J.A. Logan, S.C. Wofsy, M.B. McElroy, and M.J. Prather, Tropospheric $\mathrm{OH}$ in a three-dimensional chemical tracer model: An assessment based on observations of $\mathrm{CH}_{3} \mathrm{CCl}_{3}, J$. Geophys. Res., 95, 18,441-18,472, 1990.

Tingey, D.T., M. Manning, L.C. Grothaus, and W.F. Burns, The influence of light and temperature on isoprene emission rates from live oak, $P h y-$ siol. Plant, 47, 112-118, 1979.

Trainer, M., E.J. Williams, D.D. Parrish, M.P. Buhr, E.J. Allwine, H.H. Westberg, F.C. Fehsenfeld, and S.C. Liu, Models and observations of the impact of natural hydrocarbons on rural ozone, Nature, 329, 705707, 1987

Vukovich, F.M., and J. Fishman, The climatology of summertime $\mathrm{O}_{3}$ and $\mathrm{SO}_{2}$ (1977-1981), Atmos, Environ., 20, 2423-2433, 1986.

Wendland, W.M., and R.A. Bryson, Northern hemisphere airstream regions, Mon. Weather Rev., 109, 255-270, 1981.

Wolff, G.T., and P.J. Lioy, An empirical model for forecasting maximum daily ozone levels in the northeastern U.S., J. Air Pollut. Control Assoc., 28, 1034-1038, 1978.

Wolff, G.T., and P.J. Lioy, Development of an ozone river associated with synoptic scale episodes in the eastern United States, Environ. Sci. Technol., 14, 1257-1261, 1980

G. M. Gardner, J. A. Logan, D. J. Jacob, C. M. Spivakovsky, S. C. Wofsy, and R. M. Yevich, Division of Applied Sciences and Department of Earth and Planetary Sciences, Pierce Hall, 29 Oxford Street, Harvard University, Cambridge, MA 02138-2901.

M. J. Prather, Department of Earth Sciences, University of California at Irvine, Irvine, CA 92717.

S. Sillman, Department of Atmospheric, Oceanic and Space Sciences, University of Michigan, Ann Arbor, MI 48109-2143.

(Received July 7, 1992;

revised May 5, 1993;

accepted May 6, 1993.) 